\section{Coronary haemo- dynamics and myocardial metabolism during weaning from mechanical ventilation in cardiac surgical patients}

Steven Elia MD FRCPC, $*$ Peter Liu MD FRCPC, $\dagger$ Alan Hilgenberg MD, $\S$ Charrisios Skourtis MD, $\S$ Demetrios Lappas MD\$
The present clinical study was underraken to assess the alterations in myocardial metabolism and coronary haemodynamics during weaning from mechanical ventilation in postoperative cardiac surgical patients. Global and regional myocardial blood flow and metabolism were assessed using a dual port coronary sinus-great cardiac vein thermodilution catheter in 17 patients who had undergone coronary revascularization and who were being weaned from mechanical ventilation. Anaerobic myocardial metabolism, as demonstrated by the production of myocardial lactate, manifested in 8 of 17 patients during at least one of the weaning phases. There were no differences in coronary blood flow between patients who produced myocardial lactate and those who maintained aerobic cardiac metabolism. However, lactate producers exhibited larger changes in system. ic vascular resistance and mean arterial pressure than the non-lactate producers. This metabolic manifestation of myocar-

\section{Key words}

HEART: blood flow, myocardial metabolism, ischaemia; VENTILATION: mechanical, weaning.

From the Departments of Anesthesia and Surgery, Massachusetts General Hospital, Harvard Medical School, Boston, MA; and Departments of Medicine and Anaesthesia, Toronto General Hospital, University of Toronto, Canada. $\dagger$

*Dr. Elia was a Research Fellow of the Canadian Heart Foundation at the Massachusetts General Hospital, and a Recipient of the Canadian Anacsthetists' Society Research Award.

$¥ D$ r. Liu was a Fellow of the Medical Research Council of Canada and is now a Research Scholar of the Heart and Stroke Foundation of Ontario.

Address correspondence to: Dr. Peter Liu, Toronto General Hospital, Room 1-508, Gerrard Wing, Toronto, Ontario, M5G 2C4, Canada.

Accepted for publication 6th March, 1991 dial ischaemia was not accompanied by electrocardiographic changes of ischaemia, nor presence of chest pain, and may represent another form of silent ischaemia. We conclude that despite coronary revascularization, the myocardium may remain vulnerable to ischaemic anaerobic metabolism in the immediate postoperative period.

Cette étude clinique a été menée afin d'évaluer les altérations dans le métabolisme du myocarde et l'hémodynamique des coronaires lors du sevrage de la ventilation mécanique chez les patients en période post-opératoire d' une chirurgie cardiaque. Chez 17 patients ayant subi une revascularisation coronarienne et qui étaient en sevrage de la ventilarion mécanique, le métabolisme et le débit sanguin myocardique global et régional ont été évalués à l'aide d' un cathéter à thermodilution à double lumière (sinus coronaire et grande veine coronaire). Un mérabolisme myocardique anaérobique s'est manifesté chez 8 des 17 patients durant au moins une des phases du sevrage tel que démontré par la production de lactate myocardique. Il n'y a eu aucune différence du débit sanguin coronarien entre les patients qui produisaient du lactate myocardique et ceux qui maintenaient un métabolisme cardiaque aérobique. Cependant, ceux qui produisaient du lactate avaient des changements plus importants de la résistance vasculaire systémique et de la tension artérielle moyenne que ceux qui n'en produisaient pas. Celte manifestation métabolique de l'ischémie myocardique n'était pas accompagnée de changements ischémiques à l'électrocardiogramme ni de douleurs thoraciques, et pourrait représenter une autre forme d' ischémie silencieuse. Nous concluons que le myocarde peut demeurer vulnérable au métabolisme anaérobique ischémique dans la période post-opératoire immédiate, malgré une revascularisation coronarienne.

Mechanical ventilation and positive end-expiratory pressure may affect cardiac haemodynamic performance and ventricular function. ${ }^{1,2}$ Proposed mechanisms have in- 
TABLE I Patient characteristics from group of non-lactate producers $(n=9)$

\begin{tabular}{|c|c|c|c|c|c|c|c|}
\hline $\begin{array}{l}\text { Patient } \\
\text { no. }\end{array}$ & $\begin{array}{l}\text { Agel } \\
\text { sex }\end{array}$ & $\begin{array}{l}\text { Ejection } \\
\text { fraction }\end{array}$ & $\begin{array}{l}\text { Prev } \\
\text { M.I. }\end{array}$ & $\begin{array}{l}\text { Coronary } \\
\text { anatomy }\end{array}$ & $\begin{array}{l}\text { \# of } \\
\text { grafts }\end{array}$ & Medications & Anaestheric \\
\hline 1 & $57 / M$ & NA & No & $\begin{array}{l}\text { LM 50\% } \\
\text { LAD/Circ 75\% } \\
\text { RCA } 85 \%\end{array}$ & 5 & $\begin{array}{l}\text { Propranolol, diltiazem } \\
\text { Isordil }\end{array}$ & Sufcntanil \\
\hline 2 & $60 / M$ & $73 \%$ & No & LM 50\% & 3 & Propranolol, nitroglycerin sufentanil & \\
\hline 3 & $54 / \mathrm{M}$ & $47 \%$ & Yes & $\begin{array}{l}\text { LAD } 100 \% \\
\text { Circ } 90 \% \\
\text { RCA } 80 \%\end{array}$ & 5 & Nifedipine, nitroglycerin & Sufentanil \\
\hline 4 & $62 / \mathrm{M}$ & $75 \%$ & Yes & $\begin{array}{l}\text { LAD } 60 \% \\
\text { Diag } 80 \% \\
\text { RCA } 70 \%\end{array}$ & 2 & $\begin{array}{l}\text { Propranolol, diliazem } \\
\text { isordil }\end{array}$ & Sufentanil \\
\hline 5 & $59 / \mathrm{M}$ & $61 \%$ & No & $\begin{array}{l}\text { LM } 40 \% \\
\text { LAD 70\% } \\
\text { Circ 50\% } \\
\text { RCA } 95 \%\end{array}$ & 4 & $\begin{array}{l}\text { Diltiazem, atenolol } \\
\text { nitroglycerin }\end{array}$ & Fentanyl \\
\hline 6 & $60 / M$ & $24 \%$ & Yes & $\begin{array}{l}\text { LAD 80\% } \\
\text { Circ 100\% } \\
\text { RCA 80\% }\end{array}$ & 5 & $\begin{array}{l}\text { Nifedipine, propranolol } \\
\text { isordil }\end{array}$ & Fentanyl \\
\hline 7 & $58 / \mathrm{M}$ & $57 \%$ & Yes & $\begin{array}{l}\text { LAD 50\% } \\
\text { Circ 90\% } \\
\text { RCA 100\% }\end{array}$ & 4 & $\begin{array}{l}\text { Atenolol, nifedipine } \\
\text { nitroglycerin }\end{array}$ & Fentanyl \\
\hline 8 & $56 / M$ & $54 \%$ & Yes & $\begin{array}{l}\text { LAD 75\% } \\
\text { Circ 90\% } \\
\text { RCA 90\% }\end{array}$ & 4 & Propranolol, nitroglycerin & Fentanyl \\
\hline 9 & $41 / M$ & $45 \%$ & Yes & $\begin{array}{l}\text { LAD 60\% } \\
\text { Circ 50\% }\end{array}$ & 3 & $\begin{array}{l}\text { Propranolol, diliazem } \\
\text { isordil, nitroglycerin }\end{array}$ & Fentanyl \\
\hline
\end{tabular}

$\mathrm{LAD}=$ Left anterior descending artery: Circ $=$ Circumflex coronary antery; $\mathrm{RCA}=$ Right coronary artery; M.I. = Myocardial infarction; NA $=$ Not available: $\%=$ Per cent stenosis on coronary angiogram.

cluded reduced preload to the right ventricle, increased right ventricular afterload with a consequent decrease in output to the left heart. ${ }^{3}$ Other hypotheses have included a direct mechanical effect of lung inflation on the heart and reflex neural and humoral changes initiated by lung inflation. ${ }^{4-7}$ In addition, transmural cardiac pressure changes during mechanical ventilation may influence ventricular volumes, distribution of myocardial blood flow and myocardial oxygen consumption. From the abundance of potential mechanisms it is evident that mechanical ventilation and positive end-expiratory pressure can affect the cardiovascular system in a multifactorial manner. ${ }^{8}$ In addition, there have been preliminary animal studies indicating that mechanical ventilation may alter regional myocardial blood flow, and result in changes in ventricular function and haemodynamic performance. ${ }^{9}$

Patients with coronary artery disease are also at higher risk for myocardial ischaemia, much of which is silent. However, detection of this ischaemia may be clinically difficult. Recent work indicates that the ischaemia, whether silent or symptomatic, may have similar conse- quences, thus the detection of ischaemia assumes a high priority. ${ }^{10}$ Therefore, the present clinical study was undertaken to assess the alterations in myocardial metabolism, coronary and systemic haemodynamics occurring during weaning from mechanical ventilation in postoperative coronary artery bypass patients, and to determine whether silent ischaemia occurs and what its potential medium may be.

\section{Methods}

\section{Patients}

The study population consisted of 17 patients with previously symptomatic but stable coronary artery disease scheduled to undergo coronary artery bypass surgery. Patients with valvular heart disease, congestive heart failure or unstable angina were excluded from participation in the study. The protocol had been approved by the subcommittee of human studies of the Massachusetts General Hospital and written informed consent was obtained from each patient. The patient data are summarized in Tables I and II. All patients were studied in the 
TABLE II Patient characteristics from group of lactate producers $(n=8)$

\begin{tabular}{|c|c|c|c|c|c|c|c|}
\hline $\begin{array}{l}\text { Patient } \\
\text { no. }\end{array}$ & $\begin{array}{l}\text { Agel } \\
\text { sex }\end{array}$ & $\begin{array}{l}\text { Ejection } \\
\text { fraction }\end{array}$ & $\begin{array}{l}\text { Prev } \\
\text { M.I. }\end{array}$ & $\begin{array}{l}\text { Coronary } \\
\text { anatomy }\end{array}$ & $\begin{array}{l}\text { \# of } \\
\text { grafts }\end{array}$ & Medications & Anaesthetic \\
\hline 1 & $61 / \mathrm{M}$ & $79 \%$ & Yes & $\begin{array}{l}\text { LM } 30 \% \\
\text { LAD 80\%; Diag 50\% } \\
\text { Circ } 80 \% \\
\text { RCA } 90 \%\end{array}$ & 5 & $\begin{array}{l}\text { Diltiazem, isordil } \\
\text { aldomet }\end{array}$ & Sufentanil \\
\hline 2 & $50 / \mathrm{F}$ & NA & Yes & $\begin{array}{l}\text { LAD } 20 \% \\
\text { Circ } 30 \% \\
\text { RCA } 90 \%\end{array}$ & $\begin{array}{l}4 \\
\text { (LIMA) }\end{array}$ & $\begin{array}{l}\text { Diltiazem, metoprolol } \\
\text { isordil }\end{array}$ & Sufentanil \\
\hline 3 & $64 / M$ & $50 \%$ & Yes & $\begin{array}{l}\text { LAD } 100 \% \\
\text { Circ } 70 \%\end{array}$ & $\begin{array}{l}3 \\
\text { (LIMA) }\end{array}$ & $\begin{array}{l}\text { Propranolol, nifedipine } \\
\text { nitroglycerin }\end{array}$ & Sufentanil \\
\hline 4 & $59 / \mathrm{M}$ & $54 \%$ & No & $\begin{array}{l}\text { LAD 75\% } \\
\text { RCA } 95 \%\end{array}$ & 3 & $\begin{array}{l}\text { Diltiazem, timolol } \\
\text { nitroglycerin }\end{array}$ & Sufentanil \\
\hline 5 & $60 / \mathrm{M}$ & $62 \%$ & Yes & $\begin{array}{l}\text { LM 95\% } \\
\text { LAD 100\% } \\
\text { RCA 75\% }\end{array}$ & 5 & $\begin{array}{l}\text { Nadolol, isordil } \\
\text { nitroglyccrin }\end{array}$ & Sufentanil \\
\hline 6 & $48 / \mathrm{M}$ & $68 \%$ & No & $\begin{array}{l}\text { LAD 50\% } \\
\text { Circ 80\% } \\
\text { RCA 70\% }\end{array}$ & $\begin{array}{l}4 \\
\text { (LIMA) }\end{array}$ & $\begin{array}{l}\text { Diltiazem, timolol } \\
\text { nitroglycerin }\end{array}$ & Sufentanil \\
\hline 7 & $66 / \mathrm{M}$ & $71 \%$ & No & $\begin{array}{l}\text { LAD } 80 \% \\
\text { Circ } 100 \% \\
\text { RCA } 100 \%\end{array}$ & 5 & $\begin{array}{l}\text { Propranolol, nifedipine } \\
\text { isordil, nitroglycerin }\end{array}$ & Fentanyl \\
\hline 8 & $54 / \mathrm{M}$ & $48 \%$ & No & $\begin{array}{l}\text { LAD 90\% } \\
\text { Circ 80\% } \\
\text { RCA 90\% }\end{array}$ & $\begin{array}{l}4 \\
\text { (LIMA) }\end{array}$ & $\begin{array}{l}\text { Propranolol, diltiazem } \\
\text { nitroglycerin, isordil }\end{array}$ & Fentanyl \\
\hline
\end{tabular}

$\mathrm{LM}=\mathrm{Left}$ main coronary artery; $\mathrm{LAD}=$ Left anterior descending artery: Diag = Diagonal branch of LAD;

Circ $=$ Circumflex coronary artery; RCA $=$ Right coronary artery; M.I. = Myocardial infarction: LIMA = Left internal mammary arery implant.

fasting state and were maintained on their usual medications through to the morning of surgery.

\section{Catheterization protocol and coronary blood flow measurements}

On the morning of surgery the patients were taken to the cardiac catheterization laboratory after receiving premedication of morphine $0.1 \mathrm{mg} \cdot \mathrm{kg}^{-1}$, scopolamine 0.3 $0.4 \mathrm{mg} \cdot \mathrm{kg}^{-1}$, and lorazepam $2-4 \mathrm{mg}$., iv. Routine monitors included a two-lead electrocardiogram (II, $\mathrm{V}_{5}$ ), radial arterial, and pulmonary arterial catheters. A precalibrated Baim dual port coronary thermodilution catheter was placed using local $1 \%$ lidocaine anaesthesia via the right internal jugular vein into the great cardiac vein under fluoroscopic guidance. Angiography confirmed that the distal thermistor was positioned in the great cardiac vein with the proximal thermistor at least $20 \mathrm{~mm}$ from the coronary sinus ostum, to minimize right atrial reflux contaminating coronary sinus measurements. There was no evidence of right atrial reflux as determined by the coronary sinus thermal curve, pressure tracing, as well as the oxygen content of the coronary venous blood throughout the study. One patient had been excluded from the study when both the thermal curve of the catheter and the oxygen content of the coronary sinus blood suggested the presence of right atrial reflux.

\section{Flow measurements}

Coronary sinus blood flow was measured according to a previously validated technique. ${ }^{11.12}$ For each flow measurement, body temperature $(\mathrm{Tb})$ was first recorded from the catheter thermistors; then normal saline at room temperature was injected through the distal lumen for 20-30 seconds at a constant rate of $46 \mathrm{ml} \cdot \mathrm{min}^{-1}$ by a Harvard pump. During this injection the catheter thermistors measured the temperature of the blood-injectate mixture at the site of the coronary sinus (TmCS) and the separate injectate thermistor measured the injectate temperature (Ti). Flow at the site of the coronary sinus is calculated using the specific values of TmCS in place of $\mathrm{Tm}$ in the formula where $\mathrm{Fi}$ is the injectate flow rate, $\mathrm{C}$ is the constant based on the thermal properties of blood and injectate ( $C=1.19$ for normal saline). Because the thermistors have an identical output over the range between room and body temperature, the relative values of (Tm-Ti) and ( $\mathrm{Tb}-\mathrm{Tm})$ can be measured in millimeters 
directly from the paper printout on a strip chart recorder without the need to convert the output signals into actual temperature. Coronary sinus and great cardiac vein flows were obtained in duplicate with a coefficient of variation of 0.94 .

Flow $=\frac{(\mathrm{Tm}-\mathrm{Ti}) \times \mathrm{Fi} \times \mathrm{C} \times 1.05}{(\mathrm{~Tb}-\mathrm{Tm})}$

\section{Clinical study protocol}

Each study consisted of measuring coronary sinus, great cardiac vein blood flow and cardiac output in duplicate by thermodilution, with concommitant measurements of central venous, pulmonary arterial and pulmonary capillary wedge pressure at end expiration, twenty minutes after each ventilatory change. Simultaneous blood samples from the radial artery, coronary sinus, great cardiac vein and pulmonary artery were obtained for determination of lactate concentration and oxygen content. Measurements and blood sampling were obtained while the patient was receiving synchronized intermittent mandatory ventilation (SIMV) at 7-9 breaths per minute and a tidal volume of $15 \mathrm{ml} \cdot \mathrm{kg}^{-1}$, during SIMV at half the previous rate and during continuous positive airway pressure (CPAP) of $5 \mathrm{~cm}$ of water at end expiration. The samples were collected 20 minutes after the ventilatory changes.

After undergoing coronary revascularization $14-18 \mathrm{hr}$ previously under high-dose fentanyl $\left(50-100 \mu \mathrm{g} \cdot \mathrm{kg}^{-1}\right)$ or sufentanil $\left(10-20 \mu \mathrm{g} \cdot \mathrm{kg}^{-1}\right)$ anaesthesia, patients were studied in the intensive care unit once they satisfied standard clinical criteria for weaning from mechanical ventilation. These included an absence of haemodynamic instability or cardiac ischaemia, normothermia, satisfactory alertness, satisfactory arterial blood gases while breathing an $\mathrm{FlO}_{2}<0.5$ and positive end expiratory pressure of $5 \mathrm{~cm}$ of water or less; inspiratory force more negative than $-25 \mathrm{~cm}$ water. The weaning process was monitored by continuous arterial and pulmonary arterial pressures, and electrocardiographic recording on paper (lead $V_{5}$ ), for detection of ischaemia, defined by $>1 \mathrm{~mm}$ ST segment depression for $>1$ minute.

\section{CHEMICAL ANALYSIS}

The lactate concentration of arterial and coronary sinus blood was determined by enzymatic assay using Boehringer-Mannhein lactate kits (Cat. No 124-842). The details of the test are included in the Appendix section of the manuscript.

The oxygen content of the arterial and coronary sinus blood was measured directly with the Lex $\mathrm{O}_{2}$-Con apparatus. This method utilizes a galvanic cell that produces an electric current in proportion to the oxygen content present. ${ }^{11}$ The accuracy is \pm 0.1 volumes $\%$ with a resolution of 0.1 volumes $\%$ and a reproducibility of 2.0 \pm 0.1 volumes $\%$.

\section{CALCULATIONS}

Metabolic variables during the study including myocardial oxygen consumption, lactate extraction, total body oxygen consumption and oxygen extraction were calculated according to standard formulas based on A-V content differences (details in Appendix).

Derived haemodynamic variables much as pulmonary vascular resistance and systemic vascular resistance were also calculated according to standard formulas (details in Appendix).

\section{STATISTICAL ANALYSIS}

Measurements during SIMV, SIMV at half the previous ventilatory rate and CPAP of $5 \mathrm{~cm}$ of water were analyzed with analysis of variance with repeated measures, followed by post hoc subgroup testing to compare between any SIMV and CPAP weaning modalities. A $P$ value of $<0.05$ was considered statistically significant. If there is silent ischaemia as evidenced by lactate production, major variables between lactate producers and nonlactate producers will also be compared with analysis of variance with post hoc testing, to identify potentially related variables that may be associated with lactate production. All values were expressed as mean \pm standard error of the mean.

\section{Results}

All patients tolerated the weaning process without discomfort or anxiety. Eight out of 17 patients had myocardial lactate production during at least one of the weaning phases. Two patients had myocardial lactate production during SIMV and continued to produce lactate during CPAP. In three patients, myocardial lactate release was detected only on CPAP. Finally, two patients produced myocardial lactate during SIMV/2 and one patient had myocardial lactate production during SIMV only. No electrocardiographic manifestations of ischaemia were observed during weaning.

No significant differences in systemic and coronary haemodynamics between SIMV and SIMV/2 were observed. However, CPAP was associated with significant increases in mean arterial pressure $(8.8 \%)$, mean pulmonary artery pressure (10.2\%), PCWP (9.3\%) and cardiac index (7.2\%) compared with SIMV (Figure 1). Stroke index increased $(6.7 \%)$ as did total body oxygen consumption (13\%) in the 17 patients. These changes were small but statistically significant $(P<0.05)$. Despite these haemodynamic changes, there were no significant changes in coronary blood flow or myocardial oxygen 

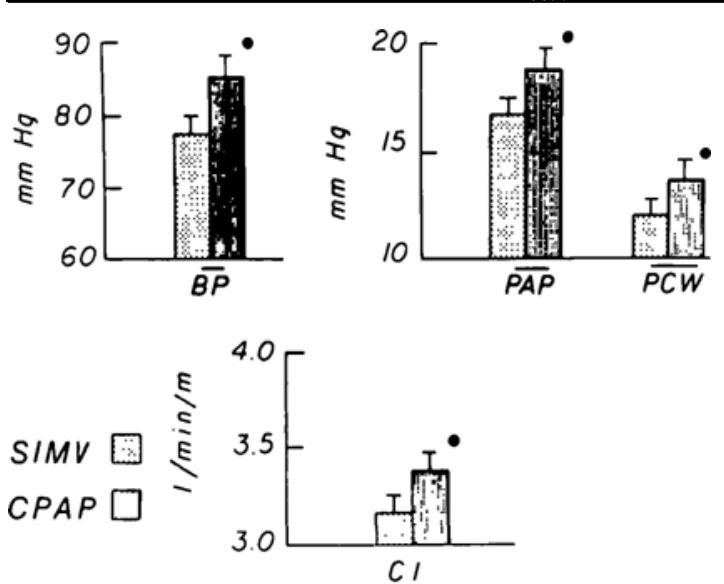

8 of $17 p t s$ produce lactate

FIGURE I Mean arterial pressure (BP). pulmonary artery pressure (PAP), pulmonary capillary wedge pressure (PCW) and cardiac index $(\mathrm{Cl})$ during weaning from SIMV to CPAP $(* P<0.05$; error bars represents SEM).

consumption during weaning from mechanical ventilation (Figure 2). Heart rates were unchanged at $90 \mathrm{~min}^{-1}$, as all patients had atrial pacing throughout weaning.

Comparison of the eight patients producing lactate with those who did not, showed that the lactate producers demonstrated greater rises in mean arterial pressure (Figure 3) and systemic vascular resistance (Figure 4) during weaning to CPAP than patients who maintained aerobic cardiac metabolism $(P<0.05)$. However, the mean changes in PCWP and cardiac index (Figure 3) during weaning were not significantly different between the two groups. Changes in coronary blood flow and myocardial oxygen consumption between the two groups were very similar (Figure 4).

\section{Discussion}

\section{Coronary and systemic haemodynamics and} myocardial metabolism during weaning

Under the conditions of our study, weaning from mechanical ventilation was associated with small but statistically significant increases in stroke volume, systemic vascular resistance and pulmonary wedge pressure. These changes occurred during withdrawal of mechanical ventilatory support and the resumption of spontaneous ventilation. Such changes in haemodynamic variables were in agreement with those observed in previous investigations of the effects of mechanical ventilation upon haemodynamics. ${ }^{1-3}$ However, in our study systemic haemodynamic changes did not influence coronary haemodynamics or myocardial oxygen consumption. Global and regional coronary flow, as well as global and regional
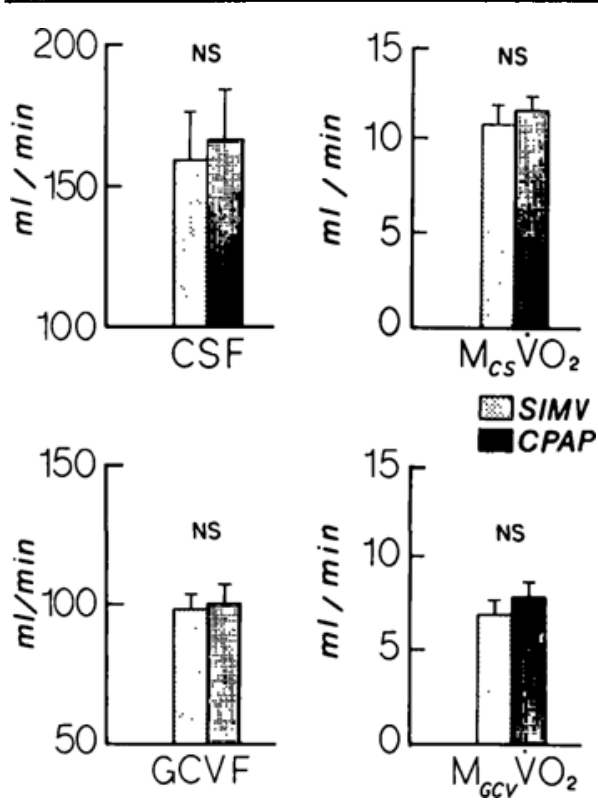

FIGURE 2 Global coronary flow and myocardial oxygen consumption as measured by coronary sinus flow (CSF) and oxygen consumption in the coronary sinus region $\left(\mathrm{M}_{\mathrm{cs}} \dot{\mathrm{v}} \mathrm{O}_{2}\right)$. Regional coronary flow and oxygen consumption as measured by great cardiac vein flow (GCVF) and oxygen consumption $\left(\mathrm{M}_{\mathrm{Gicv}} \dot{\mathrm{VO}} \mathrm{O}_{2}\right)$ during weaning from SIMV to CPAP. (NS = not significant, error bars represent SEM).

myocardial oxygen consumption were essentially unchanged. However, lactate production during weaning from mechanical ventilation occurred in 8 of 17 revascularized patients during at least one of the weaning phases. Thus, anaerobic myocardial metabolism as assessed by the coronary sinus catheter technique occurred frequently during the course of weaning postoperative coronary artery bypass patients from mechanical ventilation. The stimulus for lactate production in these eight patients does not appear to be related to coronary haemodynamic changes, which were minimal. However, the lactate producers appeared to have significant increases in systemic resistance and mean arterial pressure. One potential explanation would be the presence of regional myocardial ischaemia and dysfunction with the release of endogenous catecholamines to account for the increased systemic resistance and mean arterial pressure with a maintenance of cardiac output. Our observation of such cardiac lactate production may be a manifestation of silent cardiac ischaemia persisting into the postoperative period despite apparent revascularization.

An alternative possibility would be that endogenous catecholamine release produced subtle haemodynamic change and demand that increased myocardial metabolic demand leading to regional ischaemia. Thus, we have observed a dissociation between coronary blood flow and 


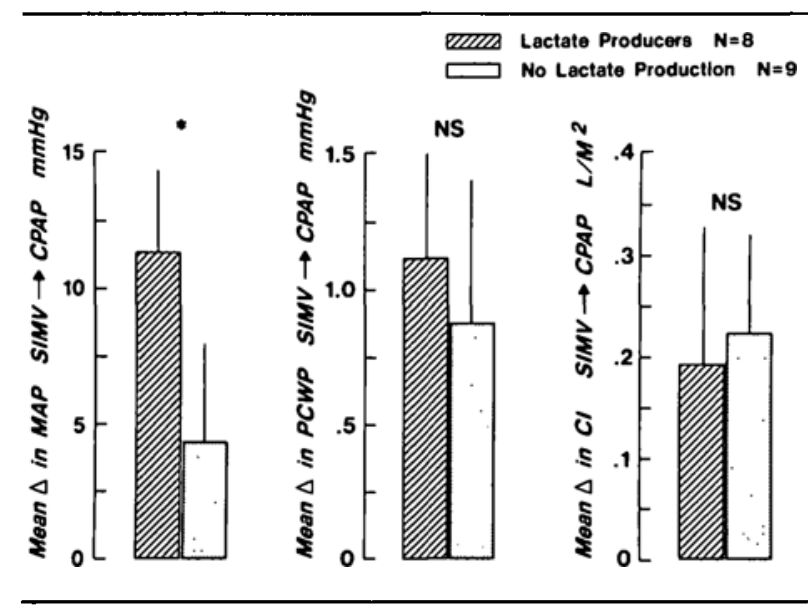

FIGURE 3 Changes in mean arterial pressure (MAP), pulmonary capillary wedge pressure (PCWP) and cardiac index (CI) between lactate producers compared to non-lactate producers during weaning from SIMV to CPAP ( ${ }^{*} P<0.05$, error bars representing SEM, NS $=$ not significant).

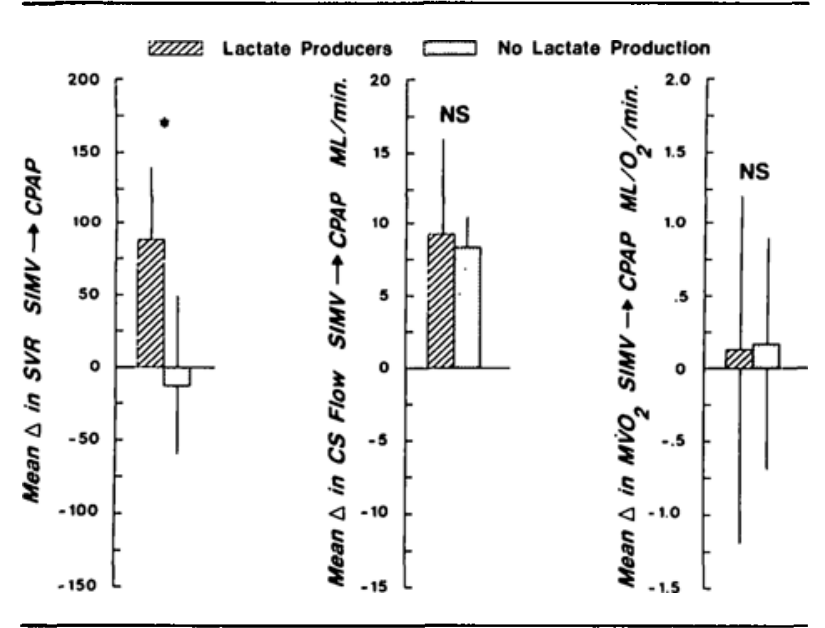

FIGURE 4 Mean changes in systemic vascular resistance (SVR), coronary sinus flow (CS flow) and myocardial oxygen consumption $\left(\mathrm{MVO}_{2}\right)$ between lactate producers and non-producers during weaning from SIMV to CPAP ( ${ }^{*} P<0.05$, error bars represent SEM, NS = not significant).

myocardial metabolism postoperatively which could represent covert metabolic ischaemia or silent cardiac ischaemia. ${ }^{12}$ Our findings extend those of a previous study where postoperative myocardial lactate production was noted in three patients in the absence of systemic haemodynamic changes or electrocardiographic changes of ischaemia. ${ }^{13}$ This implies that the revascularized myocardium still remains vulnerable to anaerobic metabolism in the postoperative period. Hypotheses that need to be explored include disturbed autoregulation of coronary blood flow in the immediate postoperative period such that small changes in coronary perfusion pressure result in large changes in regional myocardial blood flow in circumscribed areas. Such changes in regional coronary flow may have sufficiently small time constants to preclude detection by conventional coronary venous thermodilution methods. ${ }^{14}$ As well, coronary artery disease is a focal process with some myocardial areas not amenable to revascularization with such areas continuing to produce myocardial lactate. In addition, the postoperative myocardium may be depleted of essential precursors of ATP such as inosine and adenine or have sustained reperfusion injury. ${ }^{15.16}$

\section{Advantages and limitations of coronary sinus thermodilution measurements of coronary blood flow} This report is the first description of the human coronary circulation during weaning from mechanical ventilation in postoperative coronary bypass patients. Catheterization of the coronary sinus has been found to be a safe and useful method for evaluation of global changes in blood flow and metabolism of the left ventricular myocardium. ${ }^{17,18}$ By using an appropriately positioned catheter with dual sampling ports and thermistors, it is possible to perform simultaneous selective sampling and flow measurements from both the coronary sinus and great cardiac vein. ${ }^{18}$ Since the great cardiac vein represents predominantly outf low from the anterior wall of the myocardium and the coronary sinus represents the sum of the outflow from the anterior and lateral wall, this technique may permit regional assessment of myocardial blood flow and metabolism in man. Regional measurements may be important, since myocardial blood flow is heterogeneous in primates. ${ }^{19}$ Furthermore, tracer methods have confirmed that myocardial lactate metabolism is heterogeneous, and that traditional global arterio-coronary sinus lactate sampling methods do not reflect this regional heterogeneity of myocardial lactate metabolism. 19,20 Since the coronary sinus lactate level represents a mixed venous sample from the combined drainage of ischaemic and normally perfused regions of the ventricle, the net lactate level is determined by the amount of extraction in the normal region, and the relative flow contributions of the ischaemic and normal regions. For these reasons it is apparent that small focal areas of ischaemia with grossly abnormal metabolic changes in local venous effluent may not be reflected in sampling from larger downstream tributaries due to admixture from normally perfused regions with greater contributions at the sampling site. ${ }^{21}$ The presence of capability for regional measurements of coronary flow and metabolism from the great cardiac vein thus assume greater importance.

\section{Clinical significance}

In conclusion, anaerobic myocardial metabolism occurs 
frequently during weaning from mechanical ventilation in postoperative coronary bypass patients in the absence of changes in coronary haemodynamics. Silent cardiac ischaemia may extend into the postoperative period despite revascularization. Ischaemic myocardial metabolism may be present in the absence of signs that are usually used to monitor myocardial ischaemia in the postoperative period. The presence of lactate production in the absence of conventional signs of ischaemia is indicative of silent cardiac ischaemia, and occupies a more subclinical region on the spectrum of the entity of silent cardiac ischaemia. Current methods of assessing ischaemic changes require gross metabolic changes before becoming manifest as electrocardiographic or haemodynamic alterations.

Additional investigations would need to include the efficacy of maintaining anti-ischaemic therapy into the postoperative period in diminishing silent cardiac ischaemia. Further investigations also appear necessary to evaluate the frequency of silent cardiac ischaemia in patients with coronary artery disease undergoing noncardiac surgery and requiring postoperative ventilatory support.

\section{Acknowledgement}

We thank Professor Donald Baim of the Department of Medicine, Beth Israel Hospital, Harvard Medical School, for his helpful comments and suggestions for this work.

\section{Appendix}

\section{Chemical analysis}

The lactate concentration of arterial and coronary sinus blood was determined by placing $2 \mathrm{ml}$ of blood in $4 \mathrm{ml}$ of iced perchloric acid $(0.6 \mathrm{~N})$, thoroughly mixing the contents, centrifuge at $3000 \mathrm{rpm}$ for ten minutes, and subjecting the supernatant to enzymatic assay using Boehringer-Mannhein lactate kits (Cat. No 124-842). In this assay L-lactate is completely converted to pyruvate and NADH by an excess of NAD, in the presence of hydrazine as a trapping agent for pyruvate. The NADH formed during the reaction can be measured spectrophotometrically as an increase in absorbance, and linearly related to the L-lactate present. The sensitivity of this method was $0.1 \mathrm{mM} \cdot \mathrm{L}^{-1}$ of lactate and the coefficient of variation in our laboratory was $3 \%$.

\section{Calculations}

Myocardial oxygen consumption was calculated as $\mathrm{MVO}_{2}\left(\mathrm{ml} \mathrm{O}_{2} \cdot \mathrm{min}^{-1}\right)$, where $\left(\mathrm{C}_{\mathrm{a}} \mathrm{O}_{2}-\mathrm{C}_{\mathrm{cs}} \mathrm{O}_{2}\right) * \mathrm{CSBF}=$ arterial minus coronary sinus oxygen content difference $\left(\mathrm{ml} \mathrm{O} \mathrm{O}_{2} \cdot 100 \mathrm{ml}^{-1}\right)$ and $\mathrm{CSBF}=$ coronary sinus blood flow $\left(\mathrm{ml} \cdot \mathrm{min}^{-1}\right)$.
Lactate extraction percentage was calculated as (lact $\mathrm{a}_{\mathrm{a}}$ lact $\left._{c s}\right) * 100 /$ lact $_{a}$, where lact ${ }_{a}=$ arterial lactate $\left(m M \cdot L^{-1}\right)$ and lact cs $=$ coronary sinus lactate $\left(\mathrm{mM} \cdot \mathrm{L}^{-1}\right)$.

Total body oxygen consumption was calculated as $\mathrm{TBVO}_{2}\left[\left(\mathrm{ml} \mathrm{O}_{2} \cdot \mathrm{min}^{-1}\right]=\left(\mathrm{C}_{\mathrm{i}} \mathrm{O}_{2}-\mathrm{C}_{\mathrm{mv}} \mathrm{O}_{2}\right) * \mathrm{CO}\right.$ where $\mathrm{C}_{\mathrm{a}} \mathrm{O}_{2}-\mathrm{C}_{\mathrm{m}} \mathrm{VO}_{2}=$ arterial minus mixed venous oxygen content difference $\left(\mathrm{ml} \mathrm{O}_{2} / 100 \mathrm{ml}\right)$ and $\mathrm{CO}=$ cardiac output in $\mathrm{L} \cdot \mathrm{min}^{-1}$.

Oxygen extraction percentage was calculated as $\left(\mathrm{C}_{\mathrm{a}} \mathrm{O}_{2}\right.$ $\left.-\mathrm{C}_{\mathrm{cs}} \mathrm{O}_{2}\right) * 100 / \mathrm{C}_{\mathrm{a}} \mathrm{O}_{2}$, where $\mathrm{C}_{\mathrm{a}} \mathrm{O}_{2}=$ arterial oxygen content and $\mathrm{C}_{\mathrm{cs}} \mathrm{O}_{2}=$ coronary sinus oxygen content.

Systemic vascular resistance was calculated from the formula SVR (dyn-sec-cm ${ }^{-5}$ ) $=($ MAP-CVP)*80/CO, where MAP $=$ mean arterial pressure $(\mathrm{mmHg}), \mathrm{CVP}=$ central venous pressure ( $\mathrm{mmHg}$ ), and $\mathrm{CO}=$ thermodilution cardiac output.

Pulmonary vascular resistance was calculated from the formula PVR (dyn-sec-cm ${ }^{-5}$ ) $=\left(\right.$ PAP-PCWP) ${ }^{*} 80 / \mathrm{CO}$, where $\mathrm{PAP}=$ mean pulmonary artery pressure $(\mathrm{mmHg})$, and $\mathrm{PCWP}=$ pulmonary capillary wedge pressure (mmHg), and $\mathrm{CO}=$ thermodilution cardiac output.

\section{References}

1 Cournand A, Motley HL, Werko L, Richards DW. Physiological studies of the effects of intermittent positive pressure breathing on cardiac output in man. Am J Physiol 1948; 152: 162-74.

2 Rankin JS, Olsen GO, Arentzen CE et al. The effects of airway pressurc on cardiac function in intact dogs and man. Circulation 1982; 66: 108-20.

3 Luce JM. The cardiovascular effects of mechanical ventilation and positive end-expiratory pressure. JAMA 1984; 252: 807-11.

4 Robotham JL, Lixfield W, Holland $L$ et al. The effects of positive end-expiratory pressure on right and left ventricular performance. Am Rev Respir Dis 1980; 121: 677-83.

5 Glick G, Wechsler AS, Epstein SE. Reflex cardiovascular depression produced by stimulation of pulmonary stretch receptors in the dog. J Clin Invest 1969; 48: 467-73.

6 Patten MT, Liebman PR, Manny J, Sherpo D. Hechtman $H B$. Humorally mediated alterations in cardiac performance as a consequence of positive end-expiratory pressure. Surgery 1978; 84: 201-5.

7 Liebman PR, Patten MT, Manny J, Sherpo D, Hechtman $H B$. The mechanism of depressed cardiac output on positive end-expiratory pressure (PEEP). Surgery 1978; 83: 594-8.

8 Smith PK, Tyson GS, Hammon JW et al. Cardiovascular effects of ventilation with positive expiratory airway pressure. Ann Surg 1982; 195: 121-30. 
9 Venus $B$, Jacobs $H K$. Alterations in regional myocardial blood flows during different levels of positive endexpiratory pressure. Crit Care Med 1984; 12: 96-101.

10 Cohn PF. Silent myocardial ischaemia. Ann Int Med 1988; 109: 312-7.

11 Kusumi F, Butts WC, Nuff WL. Superior analytical performance by electrolytic cell analysis of blood oxygen content. J Appl Physiol 1973; 35: 299-300.

12 Singh BN, Nademanee K. Figueras J, Josephson MA. Hemodynamic and electrocardiographic correlates of symptomatic and silent myocardial ischaemia: pathophysiologic and therapeutic implications. Am J Cardiol 1986; 58: 3B-10B.

13 Moffitt EA, Scovil JE, Barker RA et al. Myocardial metabolism and haemodynamic responses during highdose fentanyl anacsthesia for coronary patients. Can Anaesth Soc J 1984; 31: 611-8.

14 Baim DS, Rothman MT, Harrison DC. Simultaneous measurement of coronary venous flow and oxygen saturation during transient alterations in myocardial oxygen supply and demand. Am J Cardiol 1982; 49: 743-52.

15 Foker JE, Einzig $S$, Wang $T$. Adenosine metabolism and myocardial preservation. Consequences of adenosine catabolism on myocardial high energy compounds and tissue blood flow. J Thorac Cardiovas Surg 1980; 80: 506-16.

$16 M c C o r d J M$. Oxygen derived free radicals in post ischaemic tissuc injury. N Engl J Med 1985; 312: 159-63.

17 Ganz W, Tamura K, Marcus HS, Donoso R, Yoshida S, Swan $H J$. Measurement of coronary sinus blood flow by continuous thermodilution in man. Circulation $1971 ; 44$ : 181-95.

18 Baim DS, Rothman MT, Harrison DC. Improved catheter for regional coronary sinus flow and metabolic studics. Am J Cardiol 1980; 46: 997-1000.

19 King BB, Bassingthwaighte JB, Hales JRS. Stability of heterogeneity of myocardial blood flow in normal awake baboons. Circ Res 1985; 57: 285-95.

20 Gertz EW, Wisneski JA, Neese R, Bristow JD, Searle GL, Hanlon JT. Myocardial lactate metabolism: evidence of lactate release during net chemical extraction in man. Circulation 1981; 63: 1273-9.

21 Owen P, Thomas $M$, Young V, Opie L. Comparison between metabolic changes in local venous and coronary sinus blood after acute experimental coronary arterial occlusion. Am J Card 1970; 25: 562-70. 